\title{
PENGARUH MODEL PEMBELAJARAN PROJECT BASED LEARNING TERHADAP KREATIFITAS BERPIKIR DAN LITERASI SAINS SISWA SMAN 1 GERUNG TAHUN 2018/2019
}

\author{
Husnul Khotimah', Suhirman², Raehanah'
}

1 Tadris Kimia, FTK UIN Mataram, Mataram. Email: raehanah@uinmataram.ac.id

2 Tadris IPA Biologi, FTK UIN Mataram, Mataram

\section{Abstrak}

Penelitian ini bertujuan untk mengetahui pengaruh model pembelajaran project based learning terhadap kreatifitas berpikir dan literasi sains siswa SMAN 1 Gerung Tahun 2018/2019 pada materi koloid. Penelitian ini merupakan penelitian quasi-eksperimen,dengan desain pretest-postest group kontrol. Pengambilan sampel menggunakan teknik sampling jenuh dengan jumlah sampel 67 orang. Data kreatifitas berpikir diambil dengan tes pilihan ganda beralasan, dan data literasi sains diambil dengan tes pilihan ganda biasa. Uji hipotesis menggunakan MANOVA. Berdasarkan hasil analisis, kesimpulan sebagai berikut; 1) Ada pengaruh yang signifikan model pembelajaran project based learning terhadap literasi sains secara multivariat (sig=0,022<0,05); 2) Ada pengaruh yang signifikan model pembelajaran project based learning terhadap kreativitas berpikir dan literasi sains (sig=0,033<0,05); 3) Ada pengaruh yang signifikan model pembelajaran project based learning terhadap literasi sains (sig=0,047<0,05).

Kata Kunci: Project Based Learning, Kreatifitas Berpikir, Literasi Sains

\section{PENDAHULUAN}

Kimia merupakan salah satu bagian mata pelajaran IPA di sekolah, untuk mempersiapkan peserta didik agar mampu berkembang menjadi anggota masyarakat yang 
melek sains (science literate) atau memiliki literasi sains yang baik. Salah satu tujuan dari mata pelajaran kimia adalah memperoleh pengalaman dalam menerapakan metode ilmiah melalui percobaan atau eksperimen, dimana peserta didik melakukan pengujian hipotesa dengan melakukan eksperimen (yang mungkin melibatkan penggunaan instrumen), pengambilan data, pengolahan dan interpretasi data, serta mengkomunikasikan hasil eksperimen secara lisan dan tertulis (Jufri, 2017).

Pembelajaran yang bermakna dapat terjadi jika siswa dapat menghubungkan antara pengetahuan yang baru dengan pengetahuan yang telah dimiliki sebelumnya (Winata, 2007). Kebermaknaan dalam pembelajaran sains bagi siswa dapat diperoleh jika siswa memiliki kemampuan literasi sains yang baik. Literasi sains menurut PISA OECD (Programme for International Student AssessmentOrganization for Economic Cooperation and Development), didefinisikan sebagai berikut:

"The capacity to use scientific knowledge, to identify questions and to draw evidence-based conclusions in order to understand and help make decisions about the natural world and the changes made to it through human activity" (Yunus, 2017).

Definisi literasi sains ini memandang literasi sains bersifat multidimensional dalam aspek pengukurannya, yaitu konten sains, proses sains, dan konteks aplikasi sains. Dengan demikian siswa mampu menggunakan pengetahuan sains dan dapat menerapkannya dalam 
memecahkan persoalan keseharian yang berkaitan dengan materi yang dipelajari.

OECD (Organisation for Economic Co-operation and Development) merupakan organisasi internasional yang concern pada perkembangan dunia pendidikan internasional. OECD secara periodik melakukan Programme for International Student Assesstment (PISA) setiap tiga tahun sekali. Salah satu aspek yang dinilai pada program ini adalah literasi sains peserta didik. Indonesia merupakan salah satu negara yang secara konsisten ikut dalam penilaian PISA. Namun, hasil yang didapatkan masih jauh dari kata memuaskan, prestasi Indonesia selalu berada di bawah standar internasional yang telah ditetapkan bahkan cenderung mengalami penurunan. Pada Tabel 1 disajikan peringkat literasi sains Indonesia sejak tahun 2000-2012 (Asyhari \& Risa, 2015).

\section{Tabel 1. Peringkat Literasi Sains Indonesia}

\begin{tabular}{ccccc}
\hline $\begin{array}{c}\text { Tahun } \\
\text { studi }\end{array}$ & $\begin{array}{c}\text { Skor rata- } \\
\text { rata } \\
\text { Indonesia }\end{array}$ & $\begin{array}{c}\text { Skor } \\
\text { maksimum }\end{array}$ & $\begin{array}{c}\text { Peringkat } \\
\text { indonesia }\end{array}$ & $\begin{array}{c}\text { Jumlah } \\
\text { negara } \\
\text { peserta studi }\end{array}$ \\
\hline 2000 & 393 & 500 & 38 & 41 \\
\hline 2003 & 395 & 500 & 38 & 40 \\
\hline 2006 & 393 & 500 & 50 & 57 \\
\hline 2009 & 383 & 500 & 60 & 65 \\
\hline 2012 & 375 & 500 & 64 & 65 \\
\hline
\end{tabular}

Sumber: OECD (2012) \& Suciati, dkk. (2014) 
Selain literasi sains, project based learning juga berpengaruh terhadap kreatifitas berpikir siswa. Kreatifitas berpikir adalah pengalaman mengekspresikan dan mengaktualisasikan identitas individu dalam bentuk terpadu dalam hubungan dengan diri sendiri dengan alam dan dengan orang lain (Hastuti, 2015). Namun kenyataannya sekarang ketika siswa diberi permasalahan cenderung memberikan jawaban yang sama, dan terkadang hanya mengikuti langkah yang ada dibuku paket atau cara yang telah ada. Belum tampak adanya penemuan ide baru maupun mengaitkan dengan dunia nyata yang dilakukan oleh siswa, dikatakan ada namun jarang sekali.

Berdasarkan hasil wawancara dengan guru kimia di SMAN 1 Gerung Lombok Barat. Guru tidak hanya mengajar dengan konvensional atau ceramah, tetapi pernah menerapkan model pembelajaran seperti jigsaw, dan membuat kelompok heterogen dengan menempatkan siswa yang pintar disetiap kelompok. Meskipun begitu guru masih belum pernah melakukan upaya untuk mengembangkan dan melatih literasi sains siswa baik pembelajaran di dalam maupun di luar kelas. Selama ini guru hanya fokus untuk meningkatkan prestasi belajar siswa yang rata-rata nilainya masih di bawah kriteria ketuntasan minimal (KKM). Tetapi setiap kali pertemuan model yang sering digunakan adalah ceramah, karena lebih simpel.

Selama ini pembelajaran sains yang dilaksanakan cenderung text book dan tidak terkait dengan kehidupan 
sehari-hari siswa, sehingga sebagian besar siswa memiliki kesulitan untuk memahami konsep-konsep sains yang berhubungan dengan kehidupannya. Kesulitan mengaplikasikan sains dalam kehidupan dapat berdampak pada perolehan prestasi belajar siswa.Untuk dapat mengembangkan literasi sains dan prestasi belajar siswa, harus ada pergeseran paradigma pembelajaran sains. Pembelajaran sains harus berpusat pada siswa, menciptakan hubungan bermakna dengan kehidupan nyata, dan harus memberikan kesempatan pada yang luas kepada siswa untuk beraktivitas baik hands on maupun minds on (Wasis, 2015).

Fenomena seperti ini, merupakan bentuk dari model pembelajaran yang kurang mendukung pada usaha pengembangan kreatifitas berpikir dan literasi sains peserta didik. Bila seorang guru, lebih senang menggunakan model pembelajara satu arah (ceramah), akan menurunkan minat gairah atau semangat belajar peserta didik, dan membekukan penalarannya. Anak akan terkondisikan tidak terbiasa berpikir dan memecahkan masalah. Model pembelajaran seperti ini hanya mengkondisikan anak menerima dan kurang aktif dalam mencari atau menemukan informasi baru untuk memecahkan masalah.

Dari pemaparan di atas, diperlukan perubahan serta inovasi dalam kegiatan pembelajaran, untuk meningkatkan kreatifitas berpikir serta literasi sains siswa. Peningkatan kreatifitas berpikir serta literasi sains siswa ini dapat dilakukan guru dengan pembelajaran menggunakan 
strategi-strategi pembelajaran konstruktivistik seperti model pembelajaran berbasis proyek (Project Based Learning). Project Based Learning merupakan sebuah pembelajaran dengan aktivitas jangka panjang yang melibatkan siswa merancang, membuat dan menampilkan produk untuk mengatasi permasalahan dunia nyata (Ridwaan, 2013). Pertimbangan lain bagi guru untuk menggunakan model pembelajaran berbasis proyek karena model ini merupakan salah satu dari tiga model pembelajaran yang sangat direkomendaskan dalam kurikulum 2013. Hal ini dikarenakan model pembelajaran berbasis proyek sejalan dengan tujuan dan amanat pembelajaran kurikulum 2013 yaitu belajar aktif (active learning).

Beberapa keuntungan yang diperoleh dengan menerapakan model pembelajaran Project Based Learning antara lain: 1) Melibatkan siswa dalam permasalahan dunia nyata yang kompleks yang membuat siswa dapat mendefiniskan isu atau permasalahan yang bermakna; 2) Membutuhkan proses inkuiri, penelitian, keterampilan merencanakan, berpikir kritis, dan keterampilan menyelesaikan masalah dalam upaya membuat proyek; 3) Melibatkan siswa dalam belajar menerapkan pengetahuan dan keterampilan dengan konteks yang bervariasi ketika bekerja membuat proyek; 4) Memberikan kesempatan pada siswa untuk belajar dan melatih keterampilan interpersonal ketika bekerja sama dalam kelompok dan orang dewasa; 5) Memberikan kesempatan pada siswa untuk melatih keterampilan yang dibutuhkan untuk hidup dan bekerja; 6) 
Mencakup aktivitas refleksi yang mengarahkan siswa untuk berpikir kritis tentang pengalaman dan menghubungkan pengalaman tersebut pada standar belajar (Ridwaan, 2013).

\section{METODE}

Penelitian ini merupakan penelitian eksperimen semu (quasi eksperimen). Desain yang digunakan dalam penelitian ini adalah pre test-post test control group design. Pre test-post test control group design adalah penelitian yang dilakukan sebanyak dua kali yaitu sebelum eksperimen (pre test), dan sesudah eksperimen (post test) (Suharsimi, 2002). Populasi penelitian ini adalah siswa kelas XI SMAN 1 Gerung tahun pelajaran 2018/2019, yang terdiri dari 2 kelas IPA. Pengambilan sampel dilakukan dengan teknik sampling jenuh. Kelas XI IPA 6 terpilih sebagai kelas eksperimen dengan jumlah siswa 34 siswa, kelas XI IPA ${ }_{2}$ terpilih sebagai kelas kontrol dengan jumlah siswa 33.

Instrumen penelitian dalam bentuk tes yaitu tes kreatifitas berpikir dan tes literasi sains. Data kreatifitas berpikir diambil dengan tes pilihan ganda beralasan, dan data literasi diambil dengan tes pilihan ganda biasa. Dalam penelitian ini penganalisisan data menggunakan teknik analisis data kuantitatif, menggunakan uji prasyarat sebagai berikut: 1) Uji normalitas data; 2) Uji general linear model; 3) Uji kesamaan matrik-kovarian. Uji hipotesis menggunakan MANOVA. 


\section{HASIL DAN PEMBAHASAN}

Secara umum hasil penelitian yang dideskripsikan pada bagian ini, yaitu skor pencapaian kreatifitas berpikir dan literasi sains siswa antara kelas eksperimen dengan kelas kontrol. Hasil penelitian disajikan pada tabel 2.

Tabel 2. Deskripsi Nilai Pretes dan Postest Kelas Eksperimen dan Kontrol

\begin{tabular}{|l|c|c|c|c|c|c|c|c|}
\hline \multirow{2}{*}{ Deskripsi } & \multicolumn{4}{|c|}{ Kelas eksperimen } & \multicolumn{4}{c|}{ kelas kontrol } \\
\cline { 2 - 9 } & \multicolumn{2}{|c|}{ Pretest } & \multicolumn{2}{c|}{ post-test } & \multicolumn{2}{c|}{ Pretest } & \multicolumn{2}{c|}{ post-test } \\
\cline { 2 - 9 } & KP & LS & KP & LS & KP & LS & KP & LS \\
\hline jumlah siswa & 34 & 34 & 34 & 34 & 33 & 33 & 33 & 33 \\
\hline nilai maksimum & 79 & 79 & 96 & 94 & 65 & 75 & 88 & 81 \\
\hline nilai minimum & 44 & 44 & 56 & 50 & 30 & 31 & 42 & 38 \\
\hline rata-rata & 60,79 & 57,35 & 76,97 & 73,59 & 50,00 & 52,82 & 62,09 & 60,67 \\
\hline standar deviasi & 8,06 & 9,88 & 12,33 & 13,86 & 8,43 & 10,25 & 14,03 & 12,79 \\
\hline
\end{tabular}

*KP: Kreatifitas berpikir

*LS: Literasi sains

Berdasarkan uji prasyarat, data kreatifitas berpikir dan literasi sains dalam penelitian ini memeiliki data normal, varian homogen dan matriks varian homogen. Sehingga analisis MANOVA untuk pengujian hipotesis dapat dilanjutkan. Pengujian hipotesis pertama menggunakan uji multivariat yang disajikan pada tabel 3 .

Berdasarkan tabel diatas diperoleh bahwa nilai signifikan sebesar sig=0,00 0,05. Artinya ada pengaruh yang signifikan model pembelajaran Project Based Learning 
terhadap kreatifitas berpikir dan literasi sanis secara multivariat. Analisis uji hipotesis kedua dan ketiga dapat dilihat pada tabel 4 .

Tabel 3. Uji hipotesis Multivariat Test

\begin{tabular}{|l|l|r|r|r|r|c|}
\hline Effect & \multicolumn{1}{|c|}{ Value } & \multicolumn{1}{c|}{$\mathbf{F}$} & $\begin{array}{c}\text { Hypothesis } \\
\text { df }\end{array}$ & Error df & Sig. \\
\hline Intercept & $\begin{array}{l}\text { Pillai's } \\
\text { Trace }\end{array}$ & .977 & $1355.952^{\mathrm{a}}$ & 2.000 & 64.000 & .000 \\
\cline { 2 - 7 } & $\begin{array}{l}\text { Wilks' } \\
\text { Lambda }\end{array}$ & .023 & $1355.952^{\mathrm{a}}$ & 2.000 & 64.000 & .000 \\
\cline { 2 - 7 } & $\begin{array}{l}\text { Hotelling's } \\
\text { Trace }\end{array}$ & 42.373 & $1355.952^{\mathrm{a}}$ & 2.000 & 64.000 & .000 \\
\cline { 2 - 7 } & $\begin{array}{l}\text { Roy's } \\
\text { Largest } \\
\text { Root }\end{array}$ & 42.373 & $1355.952^{\mathrm{a}}$ & 2.000 & 64.000 & .000 \\
\hline Kelas & $\begin{array}{l}\text { Pillai's } \\
\text { Trace }\end{array}$ & .307 & $14.172^{\mathrm{a}}$ & 2.000 & 64.000 & .000 \\
\cline { 2 - 7 } & $\begin{array}{l}\text { Wilks' } \\
\text { Lambda }\end{array}$ & .693 & $14.172^{\mathrm{a}}$ & 2.000 & 64.000 & .000 \\
\cline { 2 - 7 } & $\begin{array}{l}\text { Hotelling's } \\
\text { Trace }\end{array}$ & .443 & $14.172^{\mathrm{a}}$ & 2.000 & 64.000 & .000 \\
\cline { 2 - 7 } & $\begin{array}{l}\text { Roy's } \\
\text { Largest } \\
\text { Root }\end{array}$ & .443 & $14.172^{\mathrm{a}}$ & 2.000 & 64.000 & .000 \\
\hline
\end{tabular}




\section{Tabel 4. Uji hipotesis Tests of Between-Subjects Effect}

\begin{tabular}{|c|c|c|c|c|c|c|c|}
\hline Source & \multicolumn{2}{|c|}{$\begin{array}{c}\text { Dependent } \\
\text { Variable }\end{array}$} & $\begin{array}{l}\text { Type III Sum } \\
\text { of Squares }\end{array}$ & $d f$ & $\begin{array}{l}\text { Mean } \\
\text { Square }\end{array}$ & $\mathbf{F}$ & Sig. \\
\hline \multirow{2}{*}{$\begin{array}{l}\text { Corrected } \\
\text { Model }\end{array}$} & \multirow{2}{*}{ dimension1 } & $K P$ & $3707.705^{a}$ & 1 & 3707.705 & 21.298 & .000 \\
\hline & & LS & $2796.073^{b}$ & 1 & 2796.073 & 15.695 & .000 \\
\hline \multirow[t]{2}{*}{ Intercept } & \multirow{2}{*}{ dimension1 } & $K P$ & 323841.019 & 1 & 323841.019 & 1860.218 & .000 \\
\hline & & LS & 301841.088 & 1 & 301841.088 & 1694.335 & .000 \\
\hline \multirow[t]{2}{*}{ Kelas } & \multirow{2}{*}{ dimension1 } & $K P$ & 3707.705 & 1 & 3707.705 & 21.298 & .000 \\
\hline & & LS & 2796.073 & 1 & 2796.073 & 15.695 & .000 \\
\hline \multirow[t]{2}{*}{ Error } & \multirow{2}{*}{ dimension1 } & $K P$ & 11315.698 & 65 & 174.088 & & \\
\hline & & LS & 11579.569 & 65 & 178.147 & & \\
\hline \multirow[t]{2}{*}{ Total } & \multirow{2}{*}{ dimension1 } & $K P$ & 339972.000 & 67 & & & \\
\hline & & LS & 317152.000 & 67 & & & \\
\hline \multirow{2}{*}{$\begin{array}{l}\text { Corrected } \\
\text { Total }\end{array}$} & \multirow{2}{*}{ dimension1 } & $K P$ & 15023.403 & 66 & & & \\
\hline & & LS & 14375.642 & 66 & & & \\
\hline
\end{tabular}

Berdasarkan hasil tabel di atas terlihat bahwa nilai signifikan yang didapat pada kreatifitas berpikir dan literasi sains lebih kecil dari 0,05, sehingga hipotesis kedua Ho ditolak dan Ha diterima hal ini berarti ada pengaruh yang signifikan model pembelajaran Project Based Learning terhadap kreatifitas berpikir. Begitupun dengan hipotesis ketiga Ho ditolak dan Ha diterima, dalam artian ada pengaruh yang signifikan model pembelajaran Project Based Learning terhadap literasi sains.

Hasil pengujian hipotesis secara keseluruhan yang telah dijabarkan sebelumya menunjukkan bahwa model pembelajaran project based learning terbukti memiliki pengaruh yang lebih unggul terhadap kreatifitas berpikir 
dan literasi sains siswa dibandingkan dengan model pembelajaran konvesional. Model pembelajaran project based learning dapat mempengaruhi kreativitas berpikir, dikarenakan dalam proses pembelajaran dilatih untuk meningkatkan kreatifitas berpikir siswa, mulai dari memberikan gagasan, dan juga pada proses pengerjaan LKS secara berkelompok memiliki permasalahan yang sama sehingga siswa dapat saling mengoreksi ketika presentasi berlangsung, dan model pembelajaran project based learning juga dapat mempengaruhi literasi sains siswa hal tersebut dapat dilihat ketika proses pembuatan proyek hingga pada akhirnya mereka bisa menyelesaikannya dan jawaban dari siswa ketika presentasi mengenai proyek yang mereka buat.

Hasil penelitian ini sejalan dengan penelitian yang dilakukan oleh Jaka Afriana, dkk, hasilnya dimana aspek sikap sains pada kelas perempuan lebih tinggi dibandingkan dengan kelas laki-laki. Dimana Siswa baik laki-laki maupun perempuan menunjukkan respon positif dan senang terhadap penerapan PjBL STEM dalam pembelajaran pencemaran udara (Afriana, 2016). Hal ini juga didukung oleh penelitian Widya Astawa, dkk, yang menyatakan penggunaan model project based learning sesuai dengan komponen pembelajaran yang ideal bagi siswa. Dengan pemilihan rancangan strategi yang dapat disesuaikan dengan kondisi kelas, guru dapat mengakomodir berbagai kemampuan siswa di sekolah (Astawa dkk., 2015) . Hasil penelitian yang sama ditunjukkan oleh Desi Novita Anggun Sari, dkk, yang menyatakan kemampuan literasi sains siswa 
yang memperoleh pembelajaran project based learning berbantuan modul bermuatan literasi sains lebih baik dibandingkan siswa yang memperoleh pembelajaran ceramah disertai percobaan dan menggunakan bahan ajar yang biasa digunakan di sekolah (Sari dkk., 2017).

\section{KESIMPULAN}

Berdasarkan hasil penelitian yang telah dilakukan, setelah melalui tahap pengumpulan data, analisis data maka dihasilkan kesimpulan sebagai berikut: 1) Ada pengaruh yang signifikan model pembelajaran Project Based Learning terhadap kreatifitas berpikir dan literasi sanis secara multivariat siswa kelas XI SMAN 1 Gerung Tahun 2018/ 2019; 2) Ada pengaruh yang signifikan model pembelajaran Project Based Learning terhadap kteatifitas berpikir siswa kelas XI SMAN 1 Gerung Tahun 2018/ 2019; dan 3) Ada pengaruh yang signifikan model pembelajaran Project Based Learning terhadap literasi sains siswa kelas XI SMAN 1 Gerung Tahun 2018/ 2019.

\section{DAFTAR PUSTAKA}

Afriana, J. dkk. (2016). Penerapan Project Based Learning Terintegrasi STEM untuk Meningkatkan Literasi Sains Siswa Ditinjau dari Gender. Jurnal Inovasi Pendidikan IPA. 2(2). 202.

Astawa, W. dkk. (2015). Pengaruh Model Pembelajaran Berbasis Proyek Terhadap Sikap Ilmiah Dan Konsep Diri Siswa SMP. e-Jurnal Program Pascasarjana 
Universitas Pendidikan Ganesha Program Studi Pendidikan IPA. 5(2). 1.

Asyhari, A. dan Risa H. (2015). Profil Peningkatan Kemampuan Literasi Sains Siswa Melalui Pembelajaran Saintifik. Jurnal IImiah Pendidikan Fisika Al-Birunni. 2(4). 180.

Hastuti, L.A. (2015). Analisis Penyebab Rendahnya Kreatifitas dan Motivasi Belajar Matematika di SDN 04 Tegalgede Tahun 2015. (Skripsi). Surakarta: Universitas Muhammadiyah Surakarta.

Jufri,W. (2017). Belajar dan Pembelajaran Sains: Modal Dasar Menjadi Guru Profesional. Bandung: Pustaka Rineka Cipta.

Ridwaan, A.S. (2017). Pembelajaran Saintifik untuk Implementasi Kurikulum 2013. Jakarta: Bumi Aksara.

Sari, D. dkk. Pengaruh Pembelajaran Berbasis Proyek Terhadap Kemampuan Literasi Sains Siswa. Pancasakti Science Education Journal. 2(2). 114.

Suharsimi, A. (2002). Prosedur Penelitian: Suatu Pendekatan Praktik. Jakarta: Rineka Cipta.

Wasis. (2015). Contextual Teaching and Learning (CTL) dalam Pembelajaran Fisika SMP. Jurnal Cakrawala Pendidikan. 2(2). 143.

Winata Putra dkk. (2007). Teori Belajar dan Pembelajaran. Jakarta: Universitas Terbuka. 

Khotimah et al.

Yunus, A. (2017). Pembelajaran Literasi Sains: Strategi Meningkatkan Kemampuan Literasi Matematika, Sains, Membaca, dan Menulis. Bandung: Bumi Aksara. 